\title{
The Neurological Manifestations of Post-Acute Sequelae of SARS-CoV-2 Infection
}

\author{
Narges Moghimi ${ }^{1}$ - Mario Di Napoli ${ }^{2}$. José Biller ${ }^{3}$ - James E. Siegler ${ }^{4} \cdot$ Rahul Shekhar $^{5} \cdot$ Louise D. McCullough $^{6}$. \\ Michelle S. Harkins ${ }^{5} \cdot$ Emily Hong $^{1}$ - Danielle A. Alaouieh ${ }^{1} \cdot$ Gelsomina Mansueto $^{7}$ - Afshin A. Divani ${ }^{1}$
}

Accepted: 11 June 2021 / Published online: 28 June 2021

(C) The Author(s), under exclusive licence to Springer Science+Business Media, LLC, part of Springer Nature 2021

\begin{abstract}
Purpose of Review Coronavirus disease 2019 (COVID-19), caused by the severe acute respiratory syndrome coronavirus 2 (SARS-CoV-2), is a global health challenge. This review aims to summarize the incidence, risk factors, possible pathophysiology, and proposed management of neurological manifestations of post-acute sequelae of SARS-CoV-2 infection (PASC) or neuro-PASC based on the published literature.

Recent Findings The National Institutes of Health has noted that PASC is a multi-organ disorder ranging from mild symptoms to an incapacitating state that can last for weeks or longer following recovery from initial infection with SARS-CoV-2. Various pathophysiological mechanisms have been proposed as the culprit for the development of PASC. These include, but are not limited to, direct or indirect invasion of the virus into the brain, immune dysregulation, hormonal disturbances, elevated cytokine levels due to immune reaction leading to chronic inflammation, direct tissue damage to other organs, and persistent low-grade infection. A multidisciplinary approach for the treatment of neuro-PASC will be required to diagnose and address these symptoms. Tailored rehabilitation and novel cognitive therapy protocols are as important as pharmacological treatments to treat neuro-PASC effectively.

Summary With recognizing the growing numbers of COVID-19 patients suffering from neuro-PASC, there is an urgent need to identify affected individuals early to provide the most appropriate and efficient treatments. Awareness among the general population and health care professionals about PASC is rising, and more efforts are needed to understand and treat this new emerging challenge. In this review, we summarize the relevant scientific literature about neuro-PASC.
\end{abstract}

This article is part of the Topical Collection on Neurology of Systemic Diseases

Afshin A. Divani

adivani@gmail.com

Narges Moghimi

narges.moghimi@gmail.com

Mario Di Napoli

mariodinapoli@katamail.com

José Biller

jbiller@lumc.edu

James E. Siegler

siegler.james@gmail.com

Rahul Shekhar

RShekhar@salud.unm.edu

Louise D. McCullough

louise.d.mccullough@uth.tmc.edu

Michelle S. Harkins

MHarkins@salud.unm.edu

Emily Hong

emhong@salud.unm.edu
Danielle A. Alaouieh

DAAlaouieh@salud.unm.edu

Gelsomina Mansueto

mansueto.g@inwind.it

1 Department of Neurology, School of Medicine, 1 University of New Mexico, MSC10-5620, Albuquerque, NM 87131, USA

2 Neurological Service, SS Annunziata Hospital, Sulmona, L'Aquila, Italy

3 Department of Neurology, Loyola University Chicago, Stritch School of Medicine, Maywood, IL, USA

4 Cooper Neurological Institute, Cooper University Health Care, Camden, NJ 08103, USA

5 Department of Medicine, School of Medicine, University of New Mexico, Albuquerque, NM, USA

6 Department of Neurology, McGovern Medical School, University of Texas Health Sciences Center, Houston, Texas, USA

7 Department of Advanced Medical and Surgical Sciences, University of Campania, Naples, Italy 
Keywords COVID-19 - SARS-CoV-2 · Post-Acute Sequelae of SARS-CoV-2 infection · PASC $\cdot$ Chronic fatigue syndrome · Myalgic encephalomyelitis $\cdot$ Long COVID $\cdot$ Post-COVID syndrome

\section{Introduction}

With more than 177 million documented infected cases globally and more than 3.8 million deaths (https://covid19.who.int/, as of June 20, 2021), the coronavirus disease 2019 (COVID-19) pandemic caused by the severe acute respiratory syndrome coronavirus 2 (SARS-CoV-2) has left a lasting global impact in unprecedented ways. With the increasing number of patients that have been infected, survivors of COVID-19 may be left with chronic post-viral complications similar to the previous severe acute respiratory syndrome (SARS) and Middle East respiratory syndrome pandemics [1]. Systemic and neurocognitive deficits may last only weeks but can potentially lead to lifelong disability $[2,3]$. Some studies indicate that disease severity correlates with worse and more prolonged neurological symptoms $[4,5 \cdot]$, while other studies have found no such correlation [6]. Chronic symptoms may affect multiple organs (see Fig. 1) including the brain, heart, lungs, musculoskeletal system, gastrointestinal tract, and kidneys [7-9]. The post-COVID symptoms, initially referred to as "long COVID" or "long-haul COVID," are now collectively referred to as "post-acute sequelae of SARS-CoV-2 infection" (PASC). These symptoms are expected to increase the burden on already overstretched health care systems worldwide. This review describes the incidence, risk factors, possible pathophysiology, and proposed management of neurological manifestations of PASC (neuro-PASC).

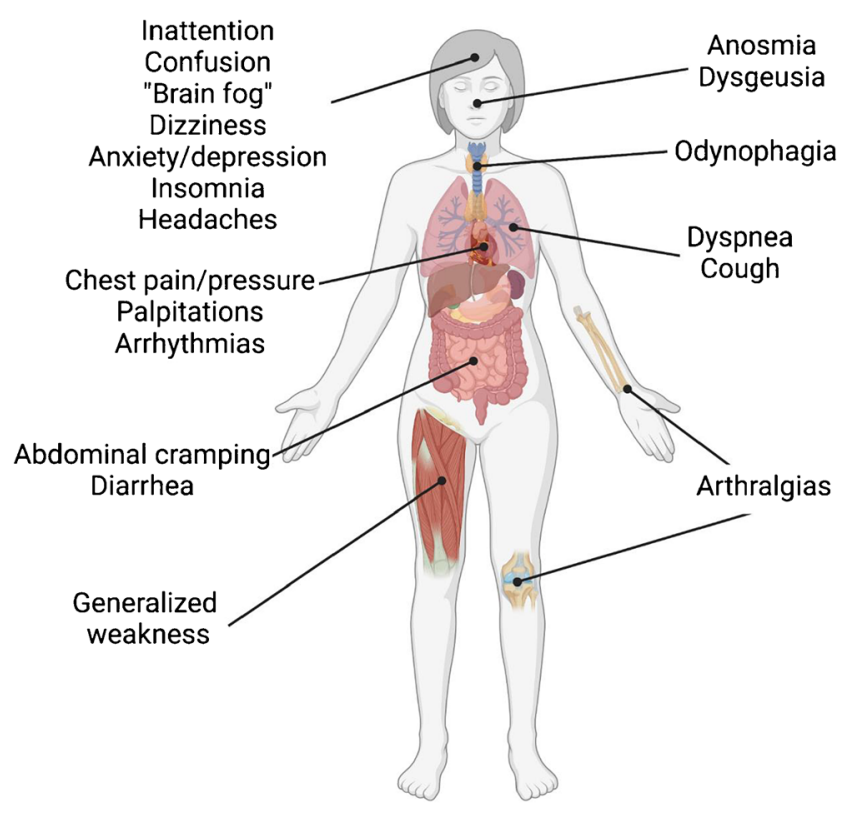

Fig. 1 Organ systems affected by PASC (the figure generated using biorender.com)

\section{Lingering COVID-19 Symptoms and PASC}

In 2021, the National Institutes of Health (NIH) noted that common symptoms of PASC include fatigue, shortness of breath, brain fog, sleep disorders, intermittent fevers, gastrointestinal symptoms, anxiety, and depression. The most commonly reported symptoms are fatigue, dyspnea, headaches, cough and chest tightness with myalgias, fever, palpitations, and other constitutional symptoms, although the list is growing [10॰]. However, the lack of a standardized definition for PASC precludes effective epidemiologic assessment of the condition, incidence rates, the impact of the condition on long-term disability, and the health care cost. Table 1 outlines PASC symptoms that have been reported in the literature so far. These symptoms, ranging from mild to severe, can persist for months, with new symptoms arising well after the time of infection [11]. Post-infectious fatigue syndromes follow in the wake of various infectious processes. Patients with postinfectious fatigue syndromes share a group of symptoms in common with patients who have myalgic encephalomyelitis/ chronic fatigue syndrome (ME/CFS).

About $80 \%$ of COVID-19 cases are asymptomatic and mild, and many patients recover within 2-4 weeks. However, severe pneumonia and critical multi-organ failure occurs in $15 \%$ and $5 \%$ of cases, respectively, and can last for 3-6 weeks [12]. Many COVID-19 survivors suffer from PASC, with the number dramatically increasing as more are infected [13]. Studies have also found that PASC can affect young adults, children, and those who had only mild COVID19 symptoms that needed neither respiratory support nor hospitalization $[14 \bullet \bullet, 15]$. PASC symptoms range from mild (e.g., slight fatigue) to severe disability (ongoing dyspnea, depression, lethargy), affecting the quality of life. Most studies have found that the severity of the disease can lead to worse or prolonged symptoms. However, one study found that this might not be the case, and more studies are needed to investigate this topic specifically [16].

An online survey of 3762 patients was conducted between December 2019 and May 2020 among patients who experienced symptoms consistent with COVID-19 [17]. Seven months after the onset of COVID-19, symptoms of persistent fatigue, post-exertional malaise, and cognitive dysfunction were reported by $77.9 \%, 71.2 \%, 56.8 \%$, and $67.5 \%$ of patients, respectively. Many were unable to work or required a reduced work schedule compared with prior to infection [17]. In an analysis of 1733 consecutive patients with laboratoryconfirmed COVID-19 (see Table 1), 76\% of patients reported at least one of the following symptoms 6 months after discharge: fatigue/muscle weakness (63\%), difficulty sleeping 


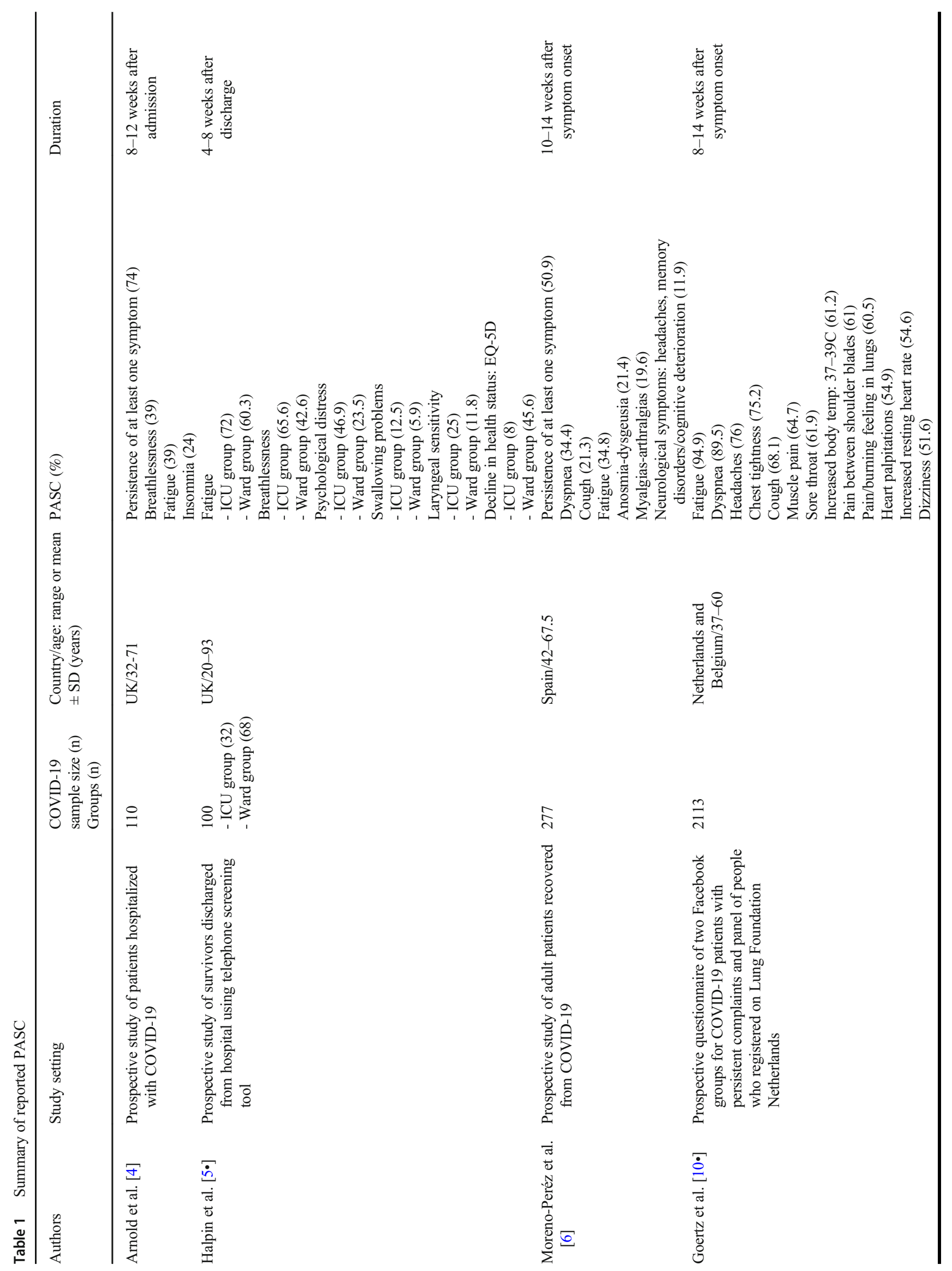




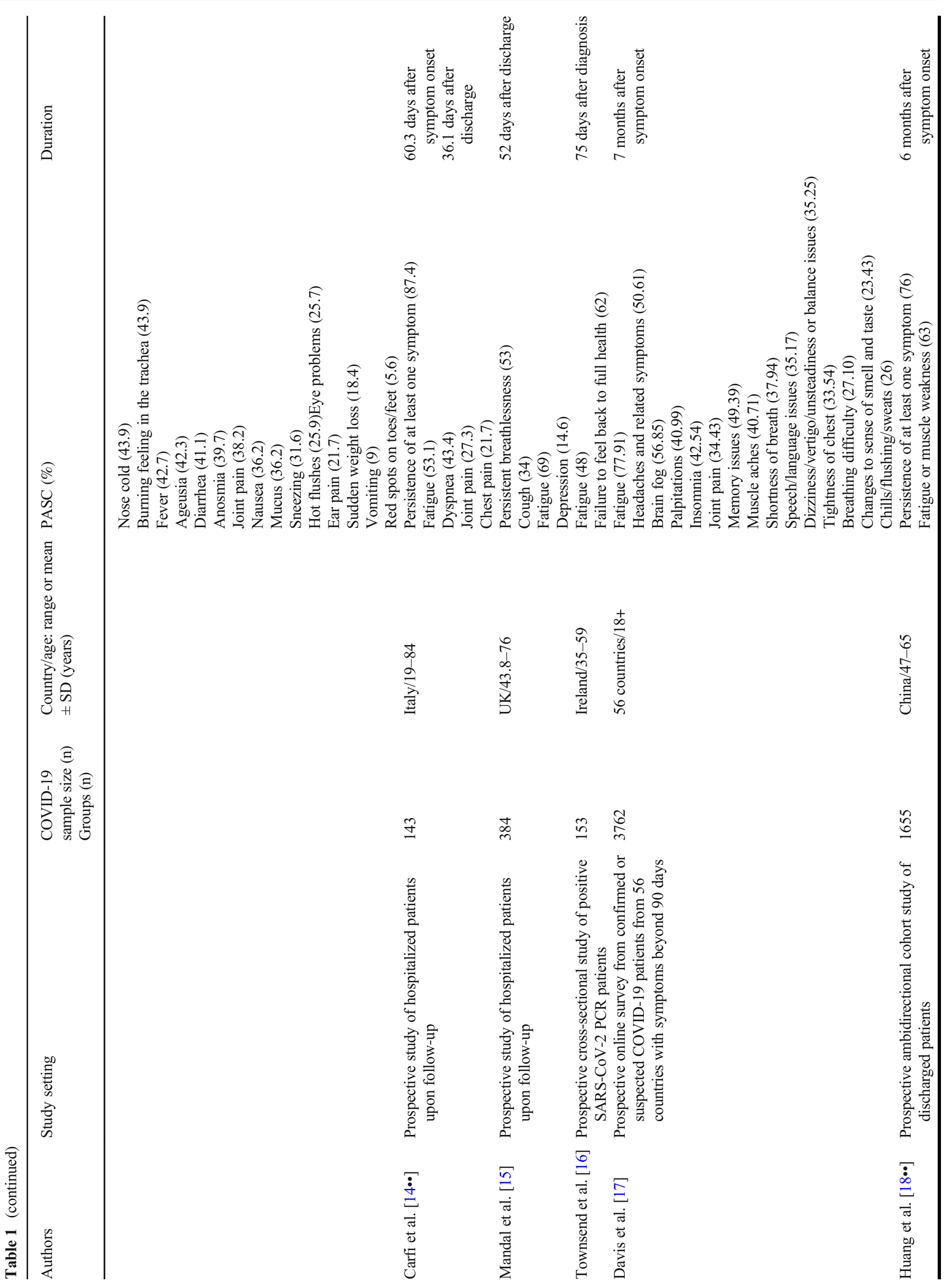




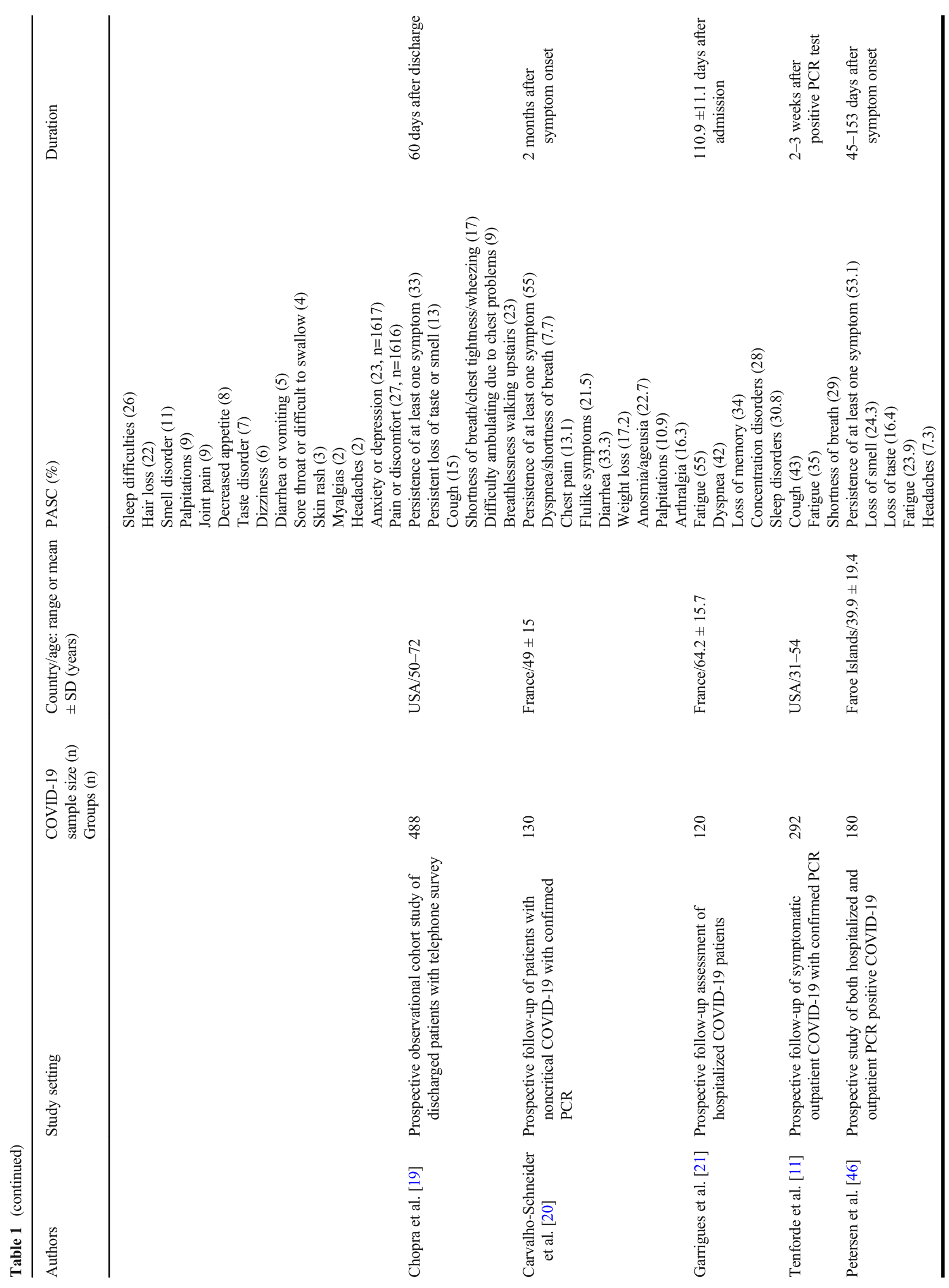


(26\%), hair loss (22\%), impaired smell and taste (11\% and $9 \%$, respectively), and trouble with mobility $(7 \%)$ [18••]. There was higher risk of fatigue or muscle weakness, pulmonary diffusion abnormalities, and anxiety or depression in severely ill patients. Similar observations have been corroborated in multicenter studies in the USA [19] and other countries $[20,21]$. Investigators from Italy $[14 \cdot \bullet]$ and other countries have reported a high prevalence of lasting systemic symptoms following diagnosis with COVID-19, which have been observed more frequently among survivors who received ICU care.

In a telephone survey of 100 hospitalized COVID-19 patients discharged at least 4 weeks prior, most patients in the survey experienced persistent symptoms [5॰]. About $72 \%$ of 32 patients who had been in the ICU reported fatigue compared with $60.3 \%$ in the non-ICU group. This suggests that PASC symptoms are not solely reflective of disease severity or ICU stay. Other common symptoms included dyspnea (65.6\% in the ICU group and $42.6 \%$ in the non-ICU group) and psychological distress (46.9\% in the ICU group and $23.5 \%$ in the non-ICU group). A decline in health status was reported by $8 \%$ of patients in the ICU group and $45.6 \%$ in the non-ICU group, as measured by the EQ-5D instrument [5•]. A multi-state telephone interview of 274 patients with mild SARS$\mathrm{CoV}-2$ also found that the majority had persistent symptoms [11]. The most common symptoms included cough (43\%), fatigue (35\%), and dyspnea (29\%). About $57 \%$ of patients with $\geq 3$ chronic conditions reported not returning to their baseline state of health and $47 \%$ of patients $\geq 50$ years reported not returning to their normal state of health [11].

\section{Post-COVID-19 Fatigue Syndrome and ME/CFS}

There are concerns about possible long-term sequelae resembling ME/CFS among COVID-19 patients. Understanding the potential mechanisms of pathogenesis and management strategies in ME/CFS patients is essential for the development of preventive and early treatment methods for "post-COVID-19 fatigue syndrome" [22].

$\mathrm{ME} / \mathrm{CFS}$ is defined as persistent or relapsing fatigue that cannot be explained by other medical or psychiatric conditions, which has been present for at least six months, is not alleviated by rest, and causes a substantial reduction in the activity of daily living (ADL) [23]. ME/CSF remains a puzzling disease after more than two decades of research [24]. Cognitive dysfunction, depression, and prolonged fatigue are related to ME/CFS [25]. Patients with postviral fatigue syndromes share a group of symptoms with ME/CFS patients. Substantial evidence supports the role of infection as a trigger of ME/CFS [26, 27] and post-viral fatigue syndrome as a possible subset of ME/CFS [28]. Previous studies suggested that CFS might be due to a non-pathogenic virus gaining access to the brain [29]. 
Historically, the symptoms of ME/CFS have been reported during earlier pandemics, including the influenza pandemics of 1889 and 1892 (Russian flu), the Spanish flu pandemic (1918-1919), and diphtheria (1921) [30]. Post-infectious fatigue syndrome is described in different infectious agents including SARS [31], Epstein-Barr virus (EBV) [32, 33], parvovirus [34], West Nile virus [35], Enteroviruses [36], Coxiella burnetii [37], human herpesvirus-6 [38], Ross River virus [33], Dengue virus [39], Ebola virus [40], Mycoplasma pneumoniae [41], Borrelia burgdorferi [42], and even parasites such as Giardia lamblia [43]. According to the literature, $\mathrm{ME} / \mathrm{CFS}$ prevalence in the USA is estimated to be between 800,000 and 3.4 million [44], and rates following viral infections vary by diagnostic techniques, population group, and case definitions [45].

In ME/CFS, a well-defined identification of a viral agent has not been made. In the case of COVID-19, we can actually try to trace the biology to get clues that will help us understand and treat patients with PASC and, potentially, people with $\mathrm{ME} / \mathrm{CFS}$. In the case of SARS-CoV-2, we have a wellidentified etiologic agent that should be very helpful in allowing us to understand ME/CFS pathophysiology. Like other viral agents, it is not surprising that SARS-CoV-2 may lead to post-infectious syndromes such as chronic fatigue. However, the rate of post-COVID fatigue appears much higher than those previously reported for EBV, Q-fever, and Ross River virus infection at a similar interval [33], with 1 in 4 post-COVID patients meeting CFS diagnostic criteria at 1 year $[31,46,47]$. The earlier post-H1N1 pandemic studies had similar findings [48]. A study by Magnus et al. about the H1N1 pandemic in Norway suggested that H1N1 infection was associated with a more than a twofold risk of CFS/EM [48].

Following SARS infection in 2009, Lam et al. reported a $27.1 \%$ incidence of ME/CFS among SARS survivors [47]. Tansey et al. confirmed high risk, long-term fatigue, and sleep disturbances among SARS survivors [49]. SARS-CoV-2 has a 79\% genetic similarity to the SARS virus [50], where fatigue incidence could reach up to $80 \%$ in the first month and $53 \%$ about 2 months after infection [49].

\section{What Causes Post-Infectious Fatigue Syndromes and ME/CFS in COVID19 patients?}

Understanding the etiology and pathophysiology of classic $\mathrm{ME} / \mathrm{CSF}$ is complicated by its broad heterogeneity but might share similar characteristics with COVID-19 induced ME/ CSF [51, 52]. Multiple models have been proposed to explain the pathogenesis of ME/CFS [26, 53, 54]. The literature suggests several potential contributing factors that may play a role in the pathophysiology of the disorder, including the persistence of viral infection, immune dysregulation, mitochondria dysfunction, changes in microbiome composition, autonomic nervous system imbalance, and alterations of neuroendocrine and brain function $[55,56]$. At present, however, none of these models has been proven to be accurate, and attempts to treat ME/CFS with antiviral drugs have been uniformly unsuccessful [57]. There might be some changes in the immune system in patients with $\mathrm{ME} / \mathrm{CFS}$; for instance, it is observed that in this group of patients, the function of NK (Natural killer cells) is impaired [58] and it is also reported the number of CD8+ T cells and B cells are increased $[59,60]$. There are inconsistent reports on cytokine levels $[61,62]$. In one observational study on adolescents with EBV infection, elevated levels of interleukin (IL)-2, IL-6, IL-8, IL-23, and interferon (IFN) $\gamma$ were seen in patients with CFS. Still, these cytokines were not elevated in patients without ME/CFS [27]. CFS patients also had a significantly higher level of IL-8 and a lower level of IL-23. Several investigators hypothesized an immune signature could be detected by antibody profiling in ME/CFS patients $[63,64]$. Few studies showed that in most cases with ME/ CFS, especially in the early stages of the disease, $\mathrm{T}$ cells and cytokines levels are higher than the control group [61, 65], which could be the hallmark of CFS. It is essential to distinguish ME/CFS from the broader mix of related and unrelated conditions. Some conditions like fibromyalgia (FM) and postural orthostatic tachycardia syndrome (POTS) have substantial symptomatic overlap with ME/CFS [66, 67]. However, there is no evidence to indicate that approved FM and POTS drugs such as pregabalin, duloxetine, and milnacipran effectively treat ME/CFS [68]. This supports the notion that ME/ CFS has unique pathophysiology.

The immune response to COVID-19 shares several characteristics with the classic pattern seen in ME/CFS [69]. Loss of plasmacytoid dendritic cells and basophils and T cell depletion, mainly CD $8+$ and $\gamma \delta \mathrm{T}$ cells, are important features of the COVID-19 immune response. The expressions of cytokines, mainly IL-6-, IL-10-, and IFN $\gamma$-induced protein 10 (IP-10, previously CXCL10), are increased, and their expression is closely correlated with disease progression [70]. IP-10 is of particular interest because its concentrations frequently remain elevated throughout the COVID-19 response similar to in ME/CFS patients [61]. Higher levels may indicate that the immune system is dealing with a greater challenge that is more likely to result in severe symptoms. However, with the lack of large and long-term longitudinal studies in COVID-19 patients, it is impossible to establish whether the reported immunological responses in the acute phase evolve over time or are correlated with long-term sequelae. The inflammatory state seen in COVID-19 patients might persist, unabated, for decades. Adipokines (leptin and resistin) have been proposed as mediators and perpetrators of chronic inflammatory diseases [71]. Several studies show that COVID-19 patients show higher levels of leptin [72, 73] and resistin [74, 75], which were identified as being important biomarkers of the immune 
response during COVID-19 infection. Thus, it is biologically plausible that changes in adipocyte tissue (in the bone marrow and/or peripheral tissues) linked to increased production of these adipokines may be a factor in the propagation of an inflammatory state in PASC.

Mitochondrial dysfunction, metabolic alterations with an increase in glycolysis, and high cytokine levels in peripheral blood mononuclear cells were demonstrated in patients with COVID-19 [76]. This is similar to other independent studies that identified ME/CFS as a hypometabolic state with impairment in multiple metabolic pathways [77] and potentially as a mitochondrial disease due to the increased mitochondrial damage, reductions in ATP production, and impaired oxidative phosphorylation [78]. Mitochondrial function in COVID19 infected patients is impaired, and these patients cannot produce their required energy by this pathway. Therefore, glycolysis is increased to compensate for high energy demands. This is associated with a higher inflammatory response [76]. Inflammasome activation leads to the production of pro-inflammatory cytokines (IL-1 $\beta$ and IL-12) and predisposition to pyroptosis [79]. Cell-free mitochondrial DNA released after pyroptosis further aggravates local and systemic inflammation [80]. Further research in this area could also provide new insights into the understanding of post-COVID19 chronic fatigue.

Recently, CFS/ME was correlated with microbial signatures of dysbiosis in the intestinal microbiota [81]. In COVID-19 patients with lower post-convalescence richness, microbiota status was not restored to normal levels 6 months post-COVID-19 [82]. There is growing evidence that gut dysbiosis is associated with the recovery process of COVID19. Targeted manipulation to promote microbial diversity could be an important strategy for treating PASC and enhancing recovery [82]. Similar to ME/CFS [54], it has been hypothesized that COVID-19 affects the autonomic nervous system [83]. The cytokine storm response of COVID-19 results from sympathetic activation inducing pro-inflammatory cytokine release [84, 85]. On the other hand, COVID-19-related autonomic dysfunction could be mediated by the virus itself into an immune-mediated neurological syndrome associated with autoantibodies (i.e., $\alpha-/ \beta$-adrenoceptors and muscarinic receptors autoantibodies) [86].

It is known that SARS-CoV-2 is a neurotropic virus that can infect and replicate in neuronal cell cultures, brain organoids, and murine brains [87-89]. Edema and neuronal degeneration along with the SARS-CoV-2 genome have been identified in the hypothalamus and pituitary tissues on autopsy studies [90]. COVID-19 has a high affinity for angiotensinconverting enzyme 2 (ACE2) receptors and potentially targets any tissue expressing ACE2, including hypothalamic and pituitary glands. Therefore, the hypothalamic-pituitary-adrenal (HPA) axis could be affected by SARS-CoV-2. Biochemical evidence of a high percentage of HPA axis involvement with central hypocortisolism and low dehydroepiandrosterone sulfate, most of which resolved within a year, was first reported by Leow et al. in SARS patients [91]. Based on this observation, the authors suggested a transient hypothalamo-pituitary dysfunction as the result of hypophysitis or direct hypothalamic damage [91].

COVID-19 patients have many different neuropsychiatric and neurological complaints such as headaches, changes in the smell and taste senses, fatigue, and myalgia. Cognitive and mood impairments are also frequently seen in these patients $[92 \bullet \bullet, 93]$. These neurological signs and symptoms are even seen in patients with mild COVID-19 symptoms, which suggests brain involvement happens in the early stages of COVID-19 [94]. Islam et al. suggested that the increase in cytokine levels such as IL-2, granulocyte-colony stimulating factor, and IP-10 may contribute to the development of longterm fatigue [95].

The brainstem has a relatively high expression of ACE2 receptors, and possibly neuropilin-1, a protein that SARSCoV-2 exploits for cell infection [96]. Young et al. hypothesized that long COVID might be related to persistent brain stem dysfunction and may be an overlooked aspect of PASC [96]. The brainstem may be affected in the early disease phase causing a compromise in respiratory, cardiovascular, gastrointestinal, and neurological function. Brainstem dysfunction has also been implicated in other chronic disorders such as migraine, chronic pain, and ME/CFS [96].

\section{Psychological Impact of COVID-19}

Social isolation, separation from loved ones, freedom loss, and helplessness have affected the global population during the pandemic [97], potentially leading to dramatic consequences such as the rise of suicides. An increasing number of young and previously fit and healthy people who did not require hospitalization continue to have symptoms months after mild COVID-19 cases. A recent survey administered during the COVID-19 pandemic has shown children and young adults are particularly at risk of developing anxiety [98-100]. Health care workers are another group particularly affected by the pandemic and stress [101]. Women are more likely to be affected by anxiety, depression, and distress [102] related to childcare issues, job loss, etc. Patients' cognitive and behavioral responses to COVID-19 and its persistent symptoms are important risk factors of long-term health issues. Therefore, pharmacological and non-pharmacological interventions for cognitive enhancement should be considered [103]. These interventions should help COVID-19 patients learn how to efficiently save energy during their routine activities, to understand their physical limitations before experiencing a worsening of their symptoms, to have better relaxation techniques, and to improve their quality of rest [104]. 
COVID-19 and dementia have many risk factors in common, including possession of $A P O E \varepsilon 4$, age, gender, hypertension, diabetes, and obesity [105]. Cognitive follow-up of COVID-19 patients will be important, especially in patients who develop neurological complications during the acute phase.

\section{A Proposal for PASC Diagnostic Criteria in Patients with Long-term Neurological Manifestations (Neuro-PASC)}

To refine guidelines for the management of patients with PASC and to characterize the long-term neurological manifestations, large-scale and multidisciplinary collaborations are needed [106]. Many have been already initiated worldwide, such as those funded by the European Academy of Neurology, the National Institute of Neurological Disorders and Stroke, the Environmental Neurology Specialty Group of the World Federation of Neurology, and Neurocritical Care Society [106-109]. However, their approaches need to be standardized, and case definitions should be used consistently across studies. Unfortunately, the clinical characterization of PASC is inadequate and, therefore, to refine guidelines for the management of COVID-19 patients with long-term neurological complications and to characterize their long-term neurological manifestations, we need a unique operational case definition to use consistently across large-scale and multidisciplinary studies.

To determine if COVID-19 is the main cause of PASC, the symptoms should appear after a confirmatory diagnosis of SARS-CoV-2 infection. However, the prevailing problem is that millions infected by SARS-CoV-2 never received a positive diagnosis due to various reasons, such as lack of access to health care or not seeking health care due to mild or no symptoms from acute infection. In neuro-PASC, we suggest including patients with the persistence of neurological symptoms beyond 3 or 4 weeks from the onset of acute symptoms of COVID-19, as replication-competent SARS-CoV-2 approaches zero after 3 to 4 weeks [56, 110, 111]. We propose the following diagnostic criteria, as summarized in Fig. 2, for an operational diagnosis of neuro-PASC. The persistence of neurological symptoms or development of sequelae due to SARS-CoV-2 infection should persist beyond 4 weeks from the onset of acute symptoms. The neurological symptoms and abnormalities present from 4 to 12 weeks beyond the acute phase of COVID-19 represent subacute neuro-PASC, while neurological symptoms and abnormalities persisting or present beyond 12 weeks and not attributable to alternative diagnoses represent chronic neuro-PACS [110, 111].

Even mild COVID-19 can result in PASC, specifically postviral fatigue in about $30-80 \%$ of cases. Although post-viral fatigue is mostly a self-limited condition, cognitive, biological, and social risk factors can put these patients at risk of having chronic conditions. Previous studies showed that the severity and duration of the acute viral infection were the main biological determinants of the risk of chronicity [104, 112]. However, recent studies on COVID-19 show a lack of association with the severity of initial infection $[6,16,113]$. This has notable implications on identifying the potential PASC and the burden on public health systems [16, 113]. It also further emphasizes the need for screening all patients diagnosed with COVID-19 for PASC.

\section{Neuro-PASC DIAGNOSTIC CRITERIA}

\begin{tabular}{|c|c|c|c|}
\hline \multicolumn{2}{|c|}{$\begin{array}{c}\text { At least } 2 \text { or } 3 \text { of following manifestations are also required in } \\
\text { a single category }\end{array}$} & \multicolumn{2}{|c|}{$\begin{array}{c}\text { Patient has at the least } 3 \text { of the following } 4 \\
\text { symptoms }\end{array}$} \\
\hline Neurologic: & $\begin{array}{l}\text { Smell/taste disturbance, myalgia, muscle } \\
\text { weakness, motor disturbance, } \\
\text { generalized hyperalgesia, neuromuscular } \\
\text { pain, new headaches, disturbed sleep } \\
\text { patterns, unrefreshing sleep drowsiness }\end{array}$ & ADL reduction: & $\begin{array}{l}\text { A substantial reduction or } \\
\text { impairment in the ability to } \\
\text { engage in pre-illness levels of } \\
\text { occupational, educational, } \\
\text { social, or personal activities }\end{array}$ \\
\hline \multirow[t]{2}{*}{ Neurocognitive: } & \multirow{2}{*}{$\begin{array}{l}\text { Difficulty thinking/processing, short-term } \\
\text { memory loss, difficulty to focus, } \\
\text { depression/anxiety, hypersensitivity to } \\
\text { noise/light, tinnitus, double vision, PTSD }\end{array}$} & & $\begin{array}{l}\text { that persists for more than } 4-6 \\
\text { weeks after diagnosis }\end{array}$ \\
\hline & & \multirow[t]{3}{*}{ Fatigue: } & \multirow{3}{*}{$\begin{array}{l}\text { The fatigue is of new or definite } \\
\text { onset (not lifelong) and is not } \\
\text { the result of ongoing excessive } \\
\text { exertion. } \\
\text { The fatigue is not substantially } \\
\text { alleviated by rest and is often } \\
\text { profound. }\end{array}$} \\
\hline Neuroendocrine: & Thermostatic instability, anorexia & & \\
\hline $\begin{array}{l}\text { Autonomic } \\
\text { dysfunction: }\end{array}$ & $\begin{array}{l}\text { Orthostatic intolerance, cardiovascular, } \\
\text { respiratory gastro-intestinal (GI), genito- } \\
\text { urinary (GU) }\end{array}$ & & \\
\hline Immune system: & $\begin{array}{l}\text { Fever or chills, flu-like symptoms, } \\
\text { susceptibility to virus, sore throat, lymph } \\
\text { node pain/tenderness, sensitivity to } \\
\text { chemicals ( foods,medications, or odors) }\end{array}$ & $\begin{array}{l}\text { Neuromuscular } \\
\text { symptoms: }\end{array}$ & $\begin{array}{l}\text { Chronic, debilitating pain, } \\
\text { numbness or weakness in their } \\
\text { hands, feet, arms and legs due } \\
\text { to unexplained nerve damage. }\end{array}$ \\
\hline $\begin{array}{l}\text { Laboratory } \\
\text { findings: }\end{array}$ & $\begin{array}{l}\text { Consistent with a hyperinflammatory } \\
\text { and/or hypercoagulability conditions } \\
\text { kidney insufficiency }\end{array}$ & $\begin{array}{l}\text { Neuropsychiatric } \\
\text { symptoms: }\end{array}$ & $\begin{array}{l}\text { dementia, delirium, anxiety, } \\
\text { psychotic disorder, depression, } \\
\text { and post-traumatic stress } \\
\text { disorder }\end{array}$ \\
\hline
\end{tabular}

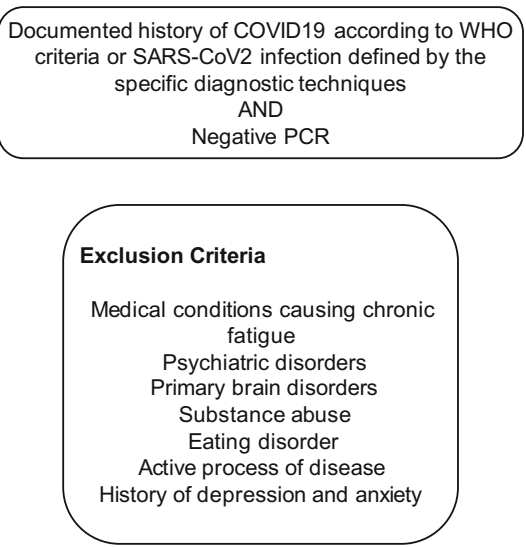

Fig. 2 Proposed neuro-PASC diagnostic criteria 


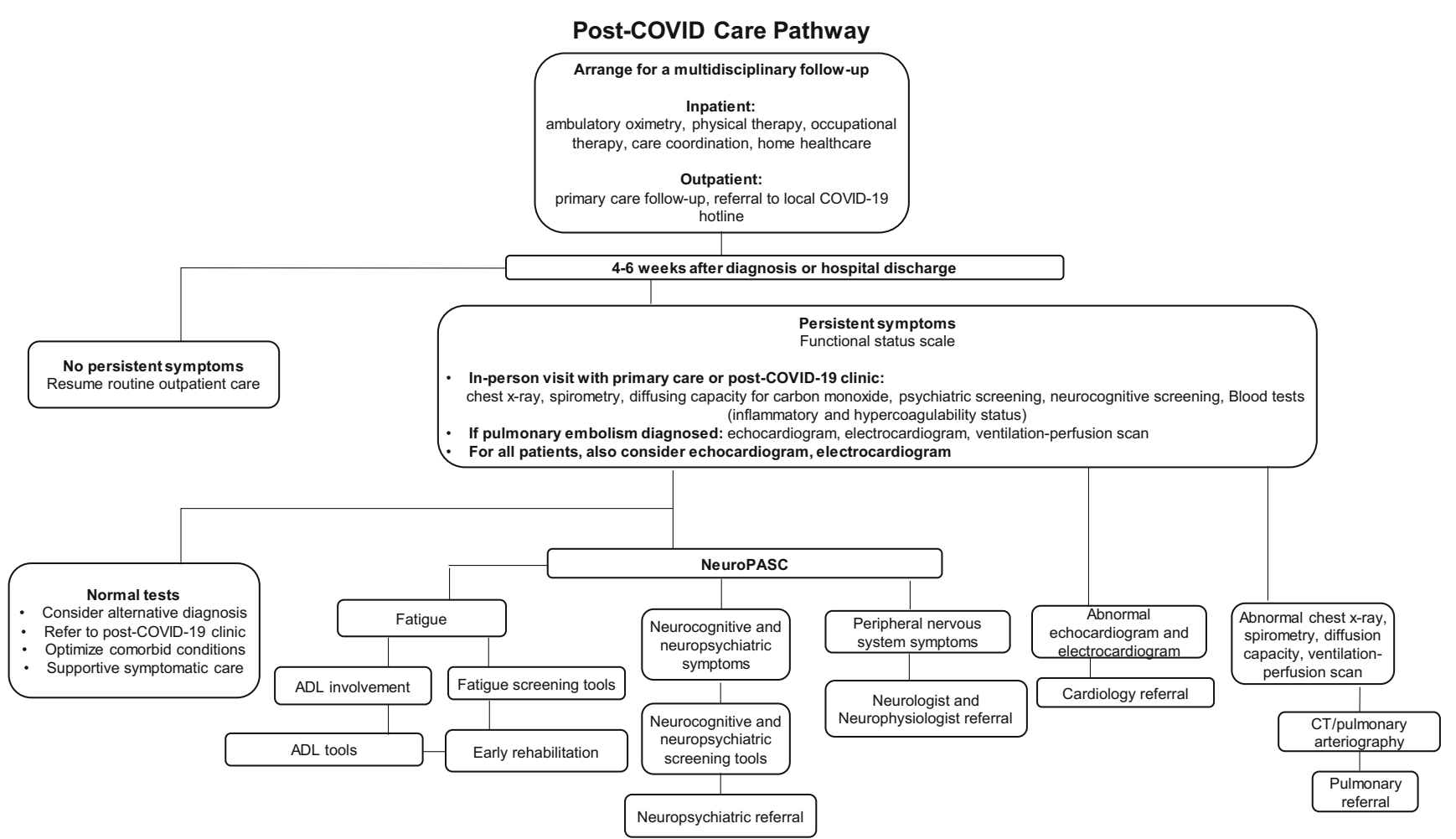

Fig. 3 A proposed post-COVID care pathway for patients with suspected neuro-PASC

In some patients with persistent fatigue following COVID19, damage of the kidney, lung, and heart may be a sufficient explanation for their chronic fatigue [114]. A chronic lowgrade neuroinflammatory response could explain postCOVID fatigue in some patients even in the absence of underlying cardiac, renal, and pulmonary conditions [108]. Advanced age is associated with increased fatigue and higher rates of chronic inflammation, often termed inflammaging $[115,116]$. Clinical outcomes of COVID-19 are significantly worse in older patients and those with comorbidities such as cardiovascular disease, pulmonary disease, diabetes, hypertension, malignancy, and immunosuppression [117, 118]. Tenforde and collaborators have also shown the same aforementioned risk factors were associated with prolonged illness in an outpatient population [11]. Nearly one out of five young adults (18-34 years old) reported they could not return to their previous routine and normal life 14-21 days after their COVID-19 test was positive. This number was significantly different in influenza survivals as $90 \%$ of patients returned to their previous state of health 2 weeks after the positive test [119]. There is also some evidence supporting a weak genetic linkage indicating the potential for offspring of classic ME/ CFS patients to be at elevated risk for the disease, which might help in understanding the possible genetic potential in COVID-19 induced ME/CSF in some patients [120].

Although some studies show the association between previous history of depression and development of severe fatigue [113, 121], other studies did not show any correlation [33].
Another strong risk factor for long-term fatigue is psychological distress during the acute and subacute phases of the viral infection [122]. Social distancing and isolation, social and economic challenges including anxiety, childcare issues, and job security, as well as elderly relatives' health concerns, etc. during COVID-19, could potentially cause more physical and psychological stress and fatigue compared to other infections [104, 123].

\section{A Follow-up Clinical Pathway for PASC Patients with Long-term Neurological Manifestations}

We propose a clinical-care pathway for patients with PASC (shown in Fig. 3). COVID-19 patients with long-term neurological manifestations should be referred to a multidisciplinary clinic. Ancillary blood tests should be ordered selectively. For example, anemia should be excluded in a patient with breathing difficulty. The British Thoracic Society proposed guideline on follow-up for COVID-19 patients with significant respiratory illness recommends a follow-up chest X-ray at 12 weeks and referral for new, persistent, or progressive symptoms (see https://www.brit-thoracic.org.uk/documentlibrary/quality-improvement/covid-19/resp-follow-upguidance-post-covid-pneumonia/). A post-COVID-19 functional status scale has been developed pragmatically but not formally validated [124]. Pulse oximeters may be extremely 
useful for assessing and monitoring respiratory symptoms after COVID-19 with no evidence that their home use leads to increased anxiety [125]. Close to $50 \%$ of COVID-19 patients who required hospital admission had hypoxia on exertion without subjective dyspnea at the time of discharge. Some of these patients even did not have chronic lung disease. Onethird of patients who were unable to complete the 6-Minute Walk Test had pulmonary embolism [126]. The 6MWT represents a useful tool for the evaluation of silent hypoxia to assess the cardiopulmonary reserve and to predict the anaerobic threshold representing a marker for combined efficiency of the lungs, heart, and circulation and marks the onset of anaerobic metabolism as a result of inadequate oxygen delivery. Ortelli et al. proposed fatigue assessment in post-COVID-19 patients by using neuropsychological and neurophysiological scales, including the Fatigue Severity Scale (FSS), Fatigue Rating Scale, Beck Depression Inventory, Apathy Evaluation Scale, cognitive tests, and computerized tasks [127]. Workup for chest pain on COVID-19 patients should be the same as other patients present with chest pain: a complete and comprehensive history including past medical history, personal and family risk factor assessment for cardiovascular events, physical examination, electrocardiography, echocardiography, chest computed tomography, and other imaging modalities such as cardiac magnetic resonance if clinically indicated [128].

\section{What Can Be Done?}

The United States Congress recently appropriated \$1.15 billion to the NIH over the next 4 years for research and clinical studies related to the long-term effect of COVID-19. Patients experiencing long-term symptoms following acute COVID19 infection are increasingly meeting criteria for ME/CFS suggestive of similar pathological processes. Furthermore, the potential benefits of the scientific insights gathered from years of treating ME/CFS for the emerging PASC have been discussed in the literature [129].

Unfortunately, the majority of patients with ME/CFS may not fully recover and do not return to their previous state of health. Also, one-third of patients may become bedridden or housebound [130]. The economic burden of ME/CFS is substantial, with unemployment rates in the range of 35-69\%. The annual cost of ME/CFS is estimated at \$18-\$24 billion in the USA [131, 132]. Currently, there is no definitive treatment for ME/CFS [52, 57]. Therapeutic approaches to ME/ CFS can be categorized into central nervous system drugs, antivirals, immunomodulators, analgesics, and nutritional supplements [132]. Antidepressants remain one of the most commonly prescribed classes of medication for $\mathrm{ME} / \mathrm{CFS}$ [132]. The monoamine oxidase inhibitor moclobemide in a randomized clinical trial (RCT) showed improvement in symptoms, but the difference was not statistically significant [133]. Using methylphenidate (Ritalin) in another doubleblinded study provided statistically significant improvement in fatigue score [134]. Ongoing studies assess the benefits of low-dose methylphenidate and mitochondrial support nutrients (called KPAX002), including acetyl-L-carnitine, $\alpha$-lipoic acid, and $N$-acetyl-cysteine [135]. Studies of antivirals treatment of $\mathrm{ME} / \mathrm{CFS}$ can be found dating as far back as 1988 [136]. Unfortunately, none of the studies had an adequate sample size [68]. Rintatolimod (a restricted toll-like receptor 3 [TLR3] agonist) has been found to increase the function of NK cells in ME/ CFS patients [137, 138]. The anti-IL6 antibody anakinra [139] and the anti-CD20 B cell depleting antibody rituximab failed to show effective response in large clinical trials [140]. Prospective cyclophosphamide trials have been reported as a potential role of autoimmunity in ME/CFS [141]. The use of steroids for treatment of ME/CSF has been shown to be ineffective [68, 142, 143]. Opioids and their derivatives such as morphine and naloxone are minimally effective [144]. Gabapentin and pregabalin could be helpful in the management of neuropathic pain in $\mathrm{ME} / \mathrm{CFS}$ patients [145]. Daily doses of NADH + CoQ10 for 8 weeks showed improved Fatigue Impact Scale total score [146]. In light of new treatments of other autoimmune diseases, Tolle and colleagues' study of immune adsorption/IgG depletion treatment in a small cohort of ME/CFS patients improved symptoms in 7 of 10 patients [147]. Understanding the potential treatment for ME/CFS patients is essential for the early pharmacological treatment methods and future research in post-COVID-19 fatigue syndrome.

The non-pharmacological approaches, such as cognitivebehavioral therapy (CBT), in non-severe ME/CFS patients show limited efficacy. In some patients undergoing CBT report lower fatigue however, the overall physical activity does not increase [148]. The UK National Institute for Care and Health Excellence (NICE) recently indicates that graded exercise therapy (GET) should no longer be considered a treatment for ME/CFS [149]. The current advancement in treating ME/ CFS will be helpful in further research in the treatment of patients with PASC, specifically patients with lingering chronic fatigue. Young suggests using pharmaceutical and non-pharmaceutical treatments currently used for similar conditions such as ME/CFS, postural orthostatic tachycardia syndrome, and mast cell activation syndrome to treat PASC [150]. We propose a summary of supplements that might be helpful in PASC (see Table 2). However, further research is required to see if these supplements are helpful in PASC to arrive at a definite treatment plan. In many cases, it appears that psychotropic drugs can be safely prescribed to patients receiving pharmacotherapy for COVID-19. For example, antidepressants (e.g., escitalopram), antipsychotics (e.g., olanzapine), benzodiazepines (lorazepam), and valproate do not seem to interact with antiviral agents such as interferon, lopinavir-ritonavir, and ribavirin [151]. 


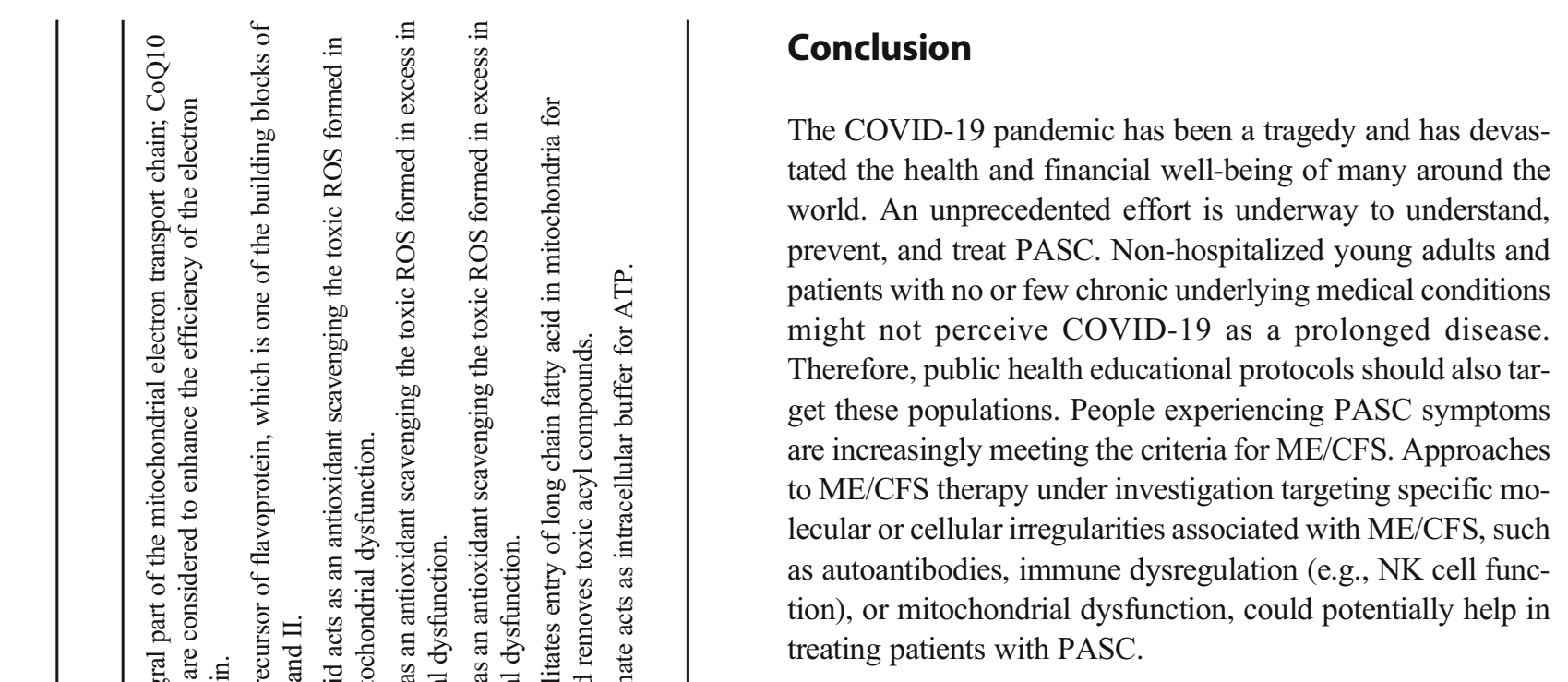

Acknowledgements The authors dedicate this work to all the innocent lives lost to COVID-19 around the world. The authors thank Dr. John Brust for reviewing this manuscript.

Code availability Not applicable.

Author contribution All the authors have contributed to preparing and revising the manuscript.

Data availability Not applicable.

\section{Declarations}

Conflict of Interest Narges Moghimi, Mario Di Napoli, José Biller, James E. Siegler, Rahul Shekhar, Louise D McCullough, Michelle S Harkins, Emily Hong, Danielle A Alaouieh, Gelsomina Mansueto, and Afshin A. Divani each declare no potential conflicts of interest.

Human and Animal Rights and Informed Consent This article does not contain any studies with human or animal subjects performed by any of the authors.

\section{References}

Papers of particular interest, published recently, have been highlighted as:

- Of importance

•. Of major importance

1. Leung TYM, Chan AYL, Chan EW, Chan VKY, Chui CSL, Cowling BJ, et al. Short- and potential long-term adverse health outcomes of COVID-19: a rapid review. Emerg Microbes Infect. 2020;9(1):2190-9. https://doi.org/10.1080/22221751.2020. 1825914.

2. Nalbandian A, Sehgal K, Gupta A, Madhavan MV, McGroder C, Stevens JS, et al. Post-acute COVID-19 syndrome. Nat Med. 2021;27(4):601-15. https://doi.org/10.1038/s41591-021-01283-Z. 
3. Mansueto G. COVID-19: brief check through the pathologist's eye (autopsy archive). Pathol Res Pract. 2020;216(11):153195. https://doi.org/10.1016/j.prp.2020.153195.

4. Arnold DT, Hamilton FW, Milne A, Morley AJ, Viner J, Attwood $\mathrm{M}$, et al. Patient outcomes after hospitalisation with COVID-19 and implications for follow-up: results from a prospective UK cohort. Thorax. 2020. https://doi.org/10.1136/thoraxjnl-2020216,086.

5. Halpin SJ, McIvor C, Whyatt G, Adams A, Harvey O, McLean L, et al. Postdischarge symptoms and rehabilitation needs in survivors of COVID-19 infection: a cross-sectional evaluation. J Med Virol. 2021;93(2):1013-22. https://doi.org/10.1002/jmv.26368 A prospective study from the UK reporting on post-COVID discharge symptoms. The study recommended rehabilitation protocols to manage post-COVID symptoms and improve functional recovery.

6. Moreno-Peréz O, Merino E, Leon-Ramirez JM, Andres M, Ramos JM, Arenas-Jimenez J, et al. Post-acute COVID-19 syndrome. Incidence and risk factors: a Mediterranean cohort study. J Inf Secur. 2021;82(3):378-83. https://doi.org/10.1016/j.jinf.2021.01.004.

7. Divani AA, Andalib S, Di Napoli M, Lattanzi S, Hussain MS, Biller J, et al. Coronavirus disease 2019 and stroke: clinical manifestations and pathophysiological insights. J Stroke Cerebrovasc Dis. $2020 ; 29(8): 104941$. https://doi.org/10.1016/j. jstrokecerebrovasdis.2020.104941.

8. Andalib S, Biller J, Di Napoli M, Moghimi N, McCullough LD, Rubinos CA, et al. Peripheral nervous system manifestations associated with COVID-19. Curr Neurol Neurosci Rep. 2021;21(3): 9. https://doi.org/10.1007/s11910-021-01102-5.

9. Divani AA, Andalib S, Biller J, Di Napoli M, Moghimi N, Rubinos CA, et al. Central nervous system manifestations associated with COVID-19. Curr Neurol Neurosci Rep. 2020;20(12):60. https://doi.org/10.1007/s11910-020-01079-7.

10. YMJ G, Van Herck M, Delbressine JM, Vaes AW, Meys R, FVC $\mathrm{M}$, et al. Persistent symptoms 3 months after a SARS-CoV-2 infection: the post-COVID-19 syndrome? ERJ Open Res. 2020;6(4). https://doi.org/10.1183/23120541.00542-2020 In previously hospitalized and non-hospitalized patients with confirmed or suspected COVID-19, multiple symptoms were present about 3 months after symptoms onset.

11. Tenforde MW, Kim SS, Lindsell CJ, Billig Rose E, Shapiro NI, Files DC, et al. Symptom duration and risk factors for delayed return to usual health among outpatients with COVID-19 in a multistate health care systems network - United States, MarchJune 2020. MMWR Morb Mortal Wkly Rep. 2020;69(30):9938. https://doi.org/10.15585/mmwr.mm6930e1.

12. Hu B, Guo H, Zhou P, Shi ZL. Characteristics of SARS-CoV-2 and COVID-19. Nat Rev Microbiol. 2021;19(3):141-54. https:// doi.org/10.1038/s41579-020-00459-7.

13. Rubin R. As their numbers grow, COVID-19 "long haulers" stump experts. JAMA. 2020;324:1381-3. https://doi.org/10. 1001/jama.2020.17709.

14.• Carfi A, Bernabei R, Landi F, Gemelli Against C-P-ACSG. Persistent symptoms in patients after acute COVID-19. JAMA. 2020;324(6):603-5. https://doi.org/10.1001/jama.2020.12603 A prospective study assessing persistent symptoms in patients who were discharged from the hospital after recovery from COVID-19.

15. Mandal S, Barnett J, Brill SE, Brown JS, Denneny EK, Hare SS et al. 'Long-COVID': a cross-sectional study of persisting symptoms, biomarker and imaging abnormalities following hospitalisation for COVID-19. Thorax. 2020. https://doi.org/10. 1136/thoraxjnl-2020-215818.

16. Townsend L, Dowds J, O’Brien K, Sheill G, Dyer AH, O'Kelly B, et al. Persistent poor health post-COVID-19 is not associated with respiratory complications or initial disease severity. Ann Am
Thorac Soc. 2021;18:997-1003. https://doi.org/10.1513/ AnnalsATS.202009-1175OC.

17. Davis HE, Assaf GS, McCorkell L, Wei H, Low RJ, Re'em Y et al. Characterizing long covid in an international cohort: 7 months of symptoms and their impact. medRxiv. 2020: 2020.12.24.20248802. doi:10.1101/2020.12.24.20248802.

18.•• Huang C, Huang L, Wang Y, Li X, Ren L, Gu X, et al. 6-month consequences of COVID-19 in patients discharged from hospital: a cohort study. Lancet. 2021;397(10270):220-32. https://doi.org/ $10.1016 / \mathrm{S} 0140-6736(20) 32656-8$ At 6 months after acute infection, COVID-19 survivors mainly suffered from fatigue or muscle weakness, sleep difficulties, and anxiety or depression. Patients who were more severely ill during their hospital stay had more severe impaired pulmonary diffusion capacities and abnormal chest imaging manifestations and were the main target population for the long-term recovery intervention.

19. Chopra V, Flanders SA, O’Malley M, Malani AN, Prescott HC. Sixty-day outcomes among patients hospitalized with COVID-19. Ann Intern Med. 2021;174(4):576-8. https://doi.org/10.7326/ M20-5661.

20. Carvalho-Schneider C, Laurent E, Lemaignen A, Beaufils E, Bourbao-Tournois C, Laribi S, et al. Follow-up of adults with noncritical COVID-19 two months after symptom onset. Clin Microbiol Infect. 2021;27(2):258-63. https://doi.org/10.1016/j. cmi.2020.09.052.

21. Garrigues E, Janvier P, Kherabi Y, Le Bot A, Hamon A, Gouze H, et al. Post-discharge persistent symptoms and health-related quality of life after hospitalization for COVID-19. J Inf Secur. 2020;81(6):e4-6. https://doi.org/10.1016/j.jinf.2020.08.029.

22. Wostyn P. COVID-19 and chronic fatigue syndrome: is the worst yet to come? Med Hypotheses. 2021;146:110469. https://doi.org/ 10.1016/j.mehy.2020.110469.

23. Fukuda K, Straus SE, Hickie I, Sharpe MC, Dobbins JG, Komaroff A. The chronic fatigue syndrome: a comprehensive approach to its definition and study. International Chronic Fatigue Syndrome Study Group. Ann Intern Med. 1994;121(12):953-9. https://doi.org/10.7326/0003-4819-121-12199412150-00009.

24. Reeves WC, Lloyd A, Vernon SD, Klimas N, Jason LA, Bleijenberg G, et al. Identification of ambiguities in the 1994 chronic fatigue syndrome research case definition and recommendations for resolution. BMC Health Serv Res. 2003;3(1):25. https://doi.org/10.1186/1472-6963-3-25.

25. Carruthers BM, van de Sande MI, De Meirleir KL, Klimas NG, Broderick G, Mitchell T, et al. Myalgic encephalomyelitis: International Consensus Criteria. J Intern Med. 2011;270(4): 327-38. https://doi.org/10.1111/j.1365-2796.2011.02428.x.

26. Blomberg J, Gottfries CG, Elfaitouri A, Rizwan M, Rosen A. Infection elicited autoimmunity and myalgic encephalomyelitis/ chronic fatigue syndrome: an explanatory model. Front Immunol. 2018;9:229. https://doi.org/10.3389/fimmu.2018.00229.

27. Broderick G, Katz BZ, Fernandes H, Fletcher MA, Klimas N, Smith FA, et al. Cytokine expression profiles of immune imbalance in post-mononucleosis chronic fatigue. J Transl Med. 2012;10:191. https://doi.org/10.1186/1479-5876-10-191.

28. Moss-Morris R, Deary V, Castell B. Chronic fatigue syndrome. Handb Clin Neurol. 2013;110:303-14. https://doi.org/10.1016/ B978-0-444-52901-5.00025-3.

29. Grinde B. Is chronic fatigue syndrome caused by a rare brain infection of a common, normally benign virus? Med Hypotheses. 2008;71(2):270-4. https://doi.org/10.1016/j.mehy. 2008.03.014.

30. Stefano GB. Historical Insight into Infections and disorders associated with neurological and psychiatric sequelae similar to long 
COVID. Med Sci Monit. 2021;27:e931447. https://doi.org/10. 12659/MSM.931447.

31. Moldofsky H, Patcai J. Chronic widespread musculoskeletal pain, fatigue, depression and disordered sleep in chronic post-SARS syndrome; a case-controlled study. BMC Neurol. 2011;11:37. https://doi.org/10.1186/1471-2377-11-37.

32. Jones JF, Ray CG, Minnich LL, Hicks MJ, Kibler R, Lucas DO. Evidence for active Epstein-Barr virus infection in patients with persistent, unexplained illnesses: elevated anti-early antigen antibodies. Ann Intern Med. 1985;102(1):1-7. https://doi.org/10. 7326/0003-4819-102-1-.

33. Hickie I, Davenport T, Wakefield D, Vollmer-Conna U, Cameron $\mathrm{B}$, Vernon SD, et al. Post-infective and chronic fatigue syndromes precipitated by viral and non-viral pathogens: prospective cohort study. BMJ. 2006;333(7568):575. https://doi.org/10.1136/bmj. 38933.585764.AE.

34. Kerr JR, Gough J, Richards SC, Main J, Enlander D, McCreary $\mathrm{M}$, et al. Antibody to parvovirus B19 nonstructural protein is associated with chronic arthralgia in patients with chronic fatigue syndrome/myalgic encephalomyelitis. J Gen Virol. 2010;91(Pt 4):893-7. https://doi.org/10.1099/vir.0.017590-0.

35. Sejvar JJ, Curns AT, Welburg L, Jones JF, Lundgren LM, Capuron L, et al. Neurocognitive and functional outcomes in persons recovering from West Nile virus illness. J Neuropsychol. 2008;2(2):477-99. https://doi.org/10.1348/174866407x218312.

36. Chia JK, Chia AY. Chronic fatigue syndrome is associated with chronic enterovirus infection of the stomach. J Clin Pathol. 2008;61(1):43-8. https://doi.org/10.1136/jcp.2007.050054.

37. Morroy G, Keijmel SP, Delsing CE, Bleijenberg G, Langendam M, Timen A, et al. Fatigue following acute Q-fever: a systematic literature review. PLoS One. 2016;11(5):e0155884. https://doi. org/10.1371/journal.pone.0155884.

38. Komaroff AL. Is human herpesvirus- 6 a trigger for chronic fatigue syndrome? J Clin Virol. 2006;37(Suppl 1):S39-46. https://doi. org/10.1016/S1386-6532(06)70010-5.

39. Seet RC, Quek AM, Lim EC. Post-infectious fatigue syndrome in dengue infection. J Clin Virol. 2007;38(1):1-6. https://doi.org/10. 1016/j.jcv.2006.10.011.

40. Epstein L, Wong KK, Kallen AJ, Uyeki TM. Post-ebola signs and symptoms in U.S. survivors. N Engl J Med. 2015;373(25):2484 6. https://doi.org/10.1056/NEJMc1506576.

41. Nicolson GL, Gan R, Haier J. Multiple co-infections (Mycoplasma, Chlamydia, human herpes virus-6) in blood of chronic fatigue syndrome patients: association with signs and symptoms. APMIS. 2003;111(5):557-66. https://doi.org/10. 1034/j.1600-0463.2003.1110504.x.

42. Sigal LH. Summary of the first 100 patients seen at a Lyme disease referral center. Am J Med. 1990;88(6):577-81. https://doi.org/10. 1016/0002-9343(90)90520-n.

43. Litleskare S, Rortveit G, Eide GE, Hanevik K, Langeland N, Wensaas KA. Prevalence of irritable bowel syndrome and chronic fatigue 10 years after giardia infection. Clin Gastroenterol Hepatol. 2018;16(7):1064-72 e4. https://doi.org/10.1016/j.cgh. 2018.01.022.

44. Valdez AR, Hancock EE, Adebayo S, Kiernicki DJ, Proskauer D, Attewell JR, et al. Estimating prevalence, demographics, and costs of ME/CFS using large scale medical claims data and machine learning. Front Pediatr. 2018;6:412. https://doi.org/10.3389/fped. 2018.00412.

45. Lim EJ, Ahn YC, Jang ES, Lee SW, Lee SH, Son CG. Systematic review and meta-analysis of the prevalence of chronic fatigue syndrome/myalgic encephalomyelitis (CFS/ME). J Transl Med. 2020;18(1):100. https://doi.org/10.1186/s12967-020-02269-0.

46. Petersen MS, Kristiansen MF, Hanusson KD, Danielsen ME, AS $\mathrm{B}$, Gaini S, et al. Long COVID in the Faroe Islands - a longitudinal study among non-hospitalized patients. Clin Infect Dis. 2020. https://doi.org/10.1093/cid/ciaa1792.

47. Lam MH, Wing YK, Yu MW, Leung CM, Ma RC, Kong AP, et al. Mental morbidities and chronic fatigue in severe acute respiratory syndrome survivors: long-term follow-up. Arch Intern Med. 2009;169(22):2142-7. https://doi.org/10.1001/ archinternmed.2009.384.

48. Magnus P, Gunnes N, Tveito K, Bakken IJ, Ghaderi S, Stoltenberg C, et al. Chronic fatigue syndrome/myalgic encephalomyelitis (CFS/ME) is associated with pandemic influenza infection, but not with an adjuvanted pandemic influenza vaccine. Vaccine. 2015;33(46):6173-7. https://doi.org/10.1016/j.vaccine. 2015.10.018.

49. Tansey CM, Louie M, Loeb M, Gold WL, Muller MP, de Jager J, et al. One-year outcomes and health care utilization in survivors of severe acute respiratory syndrome. Arch Intern Med. 2007;167(12):1312-20. https://doi.org/10.1001/archinte.167.12. 1312.

50. Lu R, Zhao X, Li J, Niu P, Yang B, Wu H, et al. Genomic characterisation and epidemiology of 2019 novel coronavirus: implications for virus origins and receptor binding. Lancet. 2020;395(10224):565-74. https://doi.org/10.1016/S01406736(20)30251-8.

51. Missailidis D, Annesley SJ, Fisher PR. Pathological mechanisms underlying myalgic encephalomyelitis/chronic fatigue syndrome. Diagnostics (Basel). 2019;9(3). https://doi.org/10.3390/ diagnostics 9030080 .

52. Smith ME, Haney E, McDonagh M, Pappas M, Daeges M, Wasson $\mathrm{N}$, et al. Treatment of myalgic encephalomyelitis/chronic fatigue syndrome: a systematic review for a National Institutes of Health Pathways to Prevention Workshop. Ann Intern Med. 2015;162(12): 841-50. https://doi.org/10.7326/M15-0114.

53. Nacul L, O'Boyle S, Palla L, Nacul FE, Mudie K, Kingdon CC, et al. How myalgic encephalomyelitis/chronic fatigue syndrome (ME/CFS) progresses: the natural history of ME/CFS. Front Neurol. 2020;11:826. https://doi.org/10.3389/fneur.2020.00826.

54. Wirth K, Scheibenbogen C. A Unifying hypothesis of the pathophysiology of myalgic encephalomyelitis/chronic fatigue syndrome (ME/CFS): recognitions from the finding of autoantibodies against ss2-adrenergic receptors. Autoimmun Rev. 2020;19(6): 102527. https://doi.org/10.1016/j.autrev.2020.102527.

55. Baig AM. Deleterious outcomes in Long-Hauler COVID-19: the effects of SARS-CoV-2 on the CNS in chronic COVID syndrome. ACS Chem Neurosci. 2020;11(24):4017-20. https://doi.org/10. 1021/acschemneuro.0c00725.

56. Greenhalgh T, Knight M, A'Court C, Buxton M, Husain L. Management of post-acute covid-19 in primary care. BMJ. 2020;370:m3026. https://doi.org/10.1136/bmj.m3026.

57. Richman S, Morris MC, Broderick G, Craddock TJA, Klimas NG, Fletcher MA. Pharmaceutical Interventions in chronic fatigue syndrome: a literature-based commentary. Clin Ther. 2019;41(5): 798-805. https://doi.org/10.1016/j.clinthera.2019.02.011.

58. Brenu EW, Hardcastle SL, Atkinson GM, van Driel ML, Kreijkamp-Kaspers S, Ashton KJ, et al. Natural killer cells in patients with severe chronic fatigue syndrome. Auto Immun Highlights. 2013;4(3):69-80. https://doi.org/10.1007/s13317013-0051-x.

59. Bradley AS, Ford B, Bansal AS. Altered functional B cell subset populations in patients with chronic fatigue syndrome compared to healthy controls. Clin Exp Immunol. 2013;172(1):73-80. https://doi.org/10.1111/cei.12043.

60. Cliff JM, King EC, Lee JS, Sepulveda N, Wolf AS, Kingdon C, et al. Cellular immune function in myalgic encephalomyelitis/ chronic fatigue syndrome (ME/CFS). Front Immunol. 2019;10: 796. https://doi.org/10.3389/fimmu.2019.00796. 
61. Montoya JG, Holmes TH, Anderson JN, Maecker HT, Rosenberg-Hasson Y, Valencia IJ, et al. Cytokine signature associated with disease severity in chronic fatigue syndrome patients. Proc Natl Acad Sci U S A. 2017;114(34):E7150-E8. https://doi. org/10.1073/pnas.1710519114.

62. Scheibenbogen C, Freitag H, Blanco J, Capelli E, Lacerda E, Authier J, et al. The European ME/CFS Biomarker Landscape project: an initiative of the European network EUROMENE. J Transl Med. 2017;15(1):162. https://doi.org/10.1186/s12967017-1263-z.

63. Gunther OP, Gardy JL, Stafford P, Fluge O, Mella O, Tang P, et al. Immunosignature analysis of myalgic encephalomyelitis/chronic fatigue syndrome (ME/CFS). Mol Neurobiol. 2019;56(6):4249-57. https://doi.org/10.1007/s12035-018-1354-8.

64. Milivojevic M, Che X, Bateman L, Cheng A, Garcia BA, Hornig $\mathrm{M}$, et al. Plasma proteomic profiling suggests an association between antigen driven clonal B cell expansion and ME/CFS. PLoS One. 2020;15(7):e0236148. https://doi.org/10.1371/journal.pone. 0236148 .

65. Hornig M, Gottschalk G, Peterson DL, Knox KK, Schultz AF, Eddy ML, et al. Cytokine network analysis of cerebrospinal fluid in myalgic encephalomyelitis/chronic fatigue syndrome. Mol Psychiatry. 2016;21(2):261-9. https://doi.org/10.1038/mp.2015.29.

66. Hoad A, Spickett G, Elliott J, Newton J. Postural orthostatic tachycardia syndrome is an under-recognized condition in chronic fatigue syndrome. QJM. 2008;101(12):961-5. https://doi.org/10. 1093/qjmed/hen123.

67. Roerink ME, Lenders JW, Schmits IC, Pistorius AM, Smit JW, Knoop H, et al. Postural orthostatic tachycardia is not a useful diagnostic marker for chronic fatigue syndrome. J Intern Med. 2017;281(2):179-88. https://doi.org/10.1111/joim.12564.

68. Kim DY, Lee JS, Park SY, Kim SJ, Son CG. Systematic review of randomized controlled trials for chronic fatigue syndrome/myalgic encephalomyelitis (CFS/ME). J Transl Med. 2020;18(1):7. https:// doi.org/10.1186/s12967-019-02196-9.

69. Wen W, Su W, Tang H, Le W, Zhang X, Zheng Y, et al. Immune cell profiling of COVID-19 patients in the recovery stage by single-cell sequencing. Cell Discov. 2020;6:31. https://doi.org/ 10.1038/s41421-020-0168-9.

70. Buszko M, Nita-Lazar A, Park JH, Schwartzberg PL, Verthelyi D, Young HA, et al. Lessons learned: new insights on the role of cytokines in COVID-19. Nat Immunol. 2021;22(4):404-11. https://doi.org/10.1038/s41590-021-00901-9.

71. Unamuno X, Gomez-Ambrosi J, Rodriguez A, Becerril S, Fruhbeck G, Catalan V. Adipokine dysregulation and adipose tissue inflammation in human obesity. Eur J Clin Investig. 2018;48(9):e12997. https://doi.org/10.1111/eci.12997.

72. van der Voort PHJ, Moser J, Zandstra DF, Muller Kobold AC, Knoester M, Calkhoven CF, et al. Leptin levels in SARS-CoV-2 infection related respiratory failure: a cross-sectional study and a pathophysiological framework on the role of fat tissue. Heliyon. 2020;6(8):e04696. https://doi.org/10.1016/j.heliyon.2020. e04696.

73. Wang J, Xu Y, Zhang X, Wang S, Peng Z, Guo J, et al. Leptin correlates with monocytes activation and severe condition in COVID-19 patients. J Leukoc Biol. 2021. https://doi.org/10. 1002/JLB.5HI1020-704R.

74. Demidowich AP, Levine JA, Apps R, Cheung FK, Chen J, Fantoni G, et al. Colchicine's effects on metabolic and inflammatory molecules in adults with obesity and metabolic syndrome: results from a pilot randomized controlled trial. Int $\mathrm{J}$ Obes. 2020;44(8):1793-9. https://doi.org/10.1038/s41366-020-0598-3.

75. Meizlish ML, Pine AB, Bishai JD, Goshua G, Nadelmann ER, Simonov M, et al. A neutrophil activation signature predicts critical illness and mortality in COVID-19. Blood Adv. 2021;5(5): 1164-77. https://doi.org/10.1182/bloodadvances.2020003568.
76. Ajaz S, McPhail MJ, Singh KK, Mujib S, Trovato FM, Napoli S, et al. Mitochondrial metabolic manipulation by SARS-CoV-2 in peripheral blood mononuclear cells of patients with COVID-19. Am J Phys Cell Phys. 2021;320(1):C57-65. https://doi.org/10. 1152/ajpcell.00426.2020.

77. Huth TK, Eaton-Fitch N, Staines D, Marshall-Gradisnik S. A systematic review of metabolomic dysregulation in Chronic Fatigue Syndrome/Myalgic Encephalomyelitis/Systemic Exertion Intolerance Disease (CFS/ME/SEID). J Transl Med. 2020;18(1): 198. https://doi.org/10.1186/s12967-020-02356-2.

78. Kenwood BM, Weaver JL, Bajwa A, Poon IK, Byrne FL, Murrow $\mathrm{BA}$, et al. Identification of a novel mitochondrial uncoupler that does not depolarize the plasma membrane. Mol Metab. 2014;3(2): 114-23. https://doi.org/10.1016/j.molmet.2013.11.005.

79. Kesavardhana S, Malireddi RKS, Kanneganti TD. Caspases in cell death, inflammation, and pyroptosis. Annu Rev Immunol. 2020;38:567-95. https://doi.org/10.1146/annurev-immunol073119-095439.

80. Riley JS, Tait SW. Mitochondrial DNA in inflammation and immunity. EMBO Rep. 2020;21(4):e49799. https://doi.org/10. 15252/embr.201949799.

81. Chen Y, Gu S, Chen Y, Lu H, Shi D, Guo J, et al. Six-month follow-up of gut microbiota richness in patients with COVID-19. Gut. 2021:gutjnl-2021-324090. https://doi.org/10.1136/gutjnl2021-324090.

82. Zuo T, Zhang F, Lui GCY, Yeoh YK, Li AYL, Zhan H, et al. Alterations in gut microbiota of patients with COVID-19 during time of hospitalization. Gastroenterology. 2020;159(3):944-55 e8. https://doi.org/10.1053/j.gastro.2020.05.048.

83. Goldstein DS. The extended autonomic system, dyshomeostasis, and COVID-19. Clin Auton Res. 2020;30(4):299-315. https://doi. org/10.1007/s10286-020-00714-0.

84. Konig MF, Powell M, Staedtke V, Bai RY, Thomas DL, Fischer $\mathrm{N}$, et al. Preventing cytokine storm syndrome in COVID-19 using alpha-1 adrenergic receptor antagonists. J Clin Invest. 2020;130(7):3345-7. https://doi.org/10.1172/JCI139642.

85. Staedtke V, Bai RY, Kim K, Darvas M, Davila ML, Riggins GJ, et al. Disruption of a self-amplifying catecholamine loop reduces cytokine release syndrome. Nature. 2018;564(7735):273-7. https://doi.org/10.1038/s41586-018-0774-y.

86. Ruzieh M, Batizy L, Dasa O, Oostra C, Grubb B. The role of autoantibodies in the syndromes of orthostatic intolerance: a systematic review. Scand Cardiovasc J. 2017;51(5):243-7. https:// doi.org/10.1080/14017431.2017.1355068.

87. Chu H, Chan JF, Yuen TT, Shuai H, Yuan S, Wang Y, et al. Comparative tropism, replication kinetics, and cell damage profiling of SARS-CoV-2 and SARS-CoV with implications for clinical manifestations, transmissibility, and laboratory studies of COVID19: an observational study. Lancet Microbe. 2020;1(1):e14-23. https://doi.org/10.1016/S2666-5247(20)30004-5.

88. Sun SH, Chen Q, Gu HJ, Yang G, Wang YX, Huang XY, et al. A mouse model of SARS-CoV-2 infection and pathogenesis. Cell Host Microbe. 2020;28(1):124-33 e4. https://doi.org/10.1016/j. chom.2020.05.020.

89. Zhang BZ, Chu H, Han S, Shuai H, Deng J, Hu YF, et al. SARSCoV-2 infects human neural progenitor cells and brain organoids. Cell Res. 2020;30(10):928-31. https://doi.org/10.1038/s41422020-0390-x.

90. Pal R. COVID-19, hypothalamo-pituitary-adrenal axis and clinical implications. Endocrine. 2020;68(2):251-2. https://doi.org/10. 1007/s12020-020-02325-1.

91. Leow MK, Kwek DS, Ng AW, Ong KC, Kaw GJ, Lee LS. Hypocortisolism in survivors of severe acute respiratory syndrome (SARS). Clin Endocrinol. 2005;63(2):197-202. https:// doi.org/10.1111/j.1365-2265.2005.02325.x. 
92.• Rogers JP, Chesney E, Oliver D, Pollak TA, McGuire P, FusarPoli P, et al. Psychiatric and neuropsychiatric presentations associated with severe coronavirus infections: a systematic review and meta-analysis with comparison to the COVID-19 pandemic. Lancet Psychiatry. 2020;7(7):611-27. https://doi.org/10.1016/ S2215-0366(20)30203-0 If SARS-CoV-2 infection follows a similar course to that with SARS or MERS, most patients should recover without experiencing mental illness. SARS$\mathrm{CoV}-2$ may cause delirium in a significant proportion of patients in the acute stage. Clinicians should be aware of the possibility of depression, anxiety, fatigue, post-traumatic stress disorder, and rarer neuropsychiatric syndromes in the chronic stage.

93. Pezzini A, Padovani A. Lifting the mask on neurological manifestations of COVID-19. Nat Rev Neurol. 2020;16(11):636-44. https://doi.org/10.1038/s41582-020-0398-3.

94. Chen X, Laurent S, Onur OA, Kleineberg NN, Fink GR, Schweitzer F, et al. A systematic review of neurological symptoms and complications of COVID-19. J Neurol. 2021;268(2): 392-402. https://doi.org/10.1007/s00415-020-10067-3.

95. Islam MF, Cotler J, Jason LA. Post-viral fatigue and COVID-19: lessons from past epidemics. Fatigue: Biomedicine, Health \& Behavior. 2020;8(2):61-9. https://doi.org/10.1080/21641846. 2020.1778227.

96. Yong SJ. persistent brainstem dysfunction in long-COVID: a hypothesis. ACS Chem Neurosci. 2021;12(4):573-80. https://doi. org/10.1021/acschemneuro.0c00793.

97. Li LZ, Wang S. Prevalence and predictors of general psychiatric disorders and loneliness during COVID-19 in the United Kingdom. Psychiatry Res. 2020;291:113267. https://doi.org/10. 1016/j.psychres.2020.113267.

98. Orgiles M, Morales A, Delvecchio E, Mazzeschi C, Espada JP. Immediate psychological effects of the COVID-19 quarantine in youth from Italy and Spain. Front Psychol. 2020;11:579038. https://doi.org/10.3389/fpsyg.2020.579038.

99. Napoli C, Tritto I, Benincasa G, Mansueto G, Ambrosio G. Cardiovascular involvement during COVID-19 and clinical implications in elderly patients. A review. Ann Med Surg (Lond). 2020;57:236-43. https://doi.org/10.1016/j.amsu.2020.07.054.

100. Napoli C, Tritto I, Mansueto G, Coscioni E, Ambrosio G. Immunosenescence exacerbates the COVID-19. Arch Gerontol Geriatr. 2020;90:104174. https://doi.org/10.1016/j.archger.2020. 104174.

101. Lai J, Ma S, Wang Y, Cai Z, Hu J, Wei N, et al. Factors associated with mental health outcomes among health care workers exposed to coronavirus disease 2019. JAMA Netw Open. 2020;3(3): e203976. https://doi.org/10.1001/jamanetworkopen.2020.3976.

102. Zanardo V, Manghina V, Giliberti L, Vettore M, Severino L, Straface G. Psychological impact of COVID-19 quarantine measures in northeastern Italy on mothers in the immediate postpartum period. Int J Gynaecol Obstet. 2020;150(2):184-8. https://doi.org/ 10.1002/ijgo.13249.

103. Dresler M, Sandberg A, Bublitz C, Ohla K, Trenado C, MroczkoWasowicz A, et al. Hacking the brain: dimensions of cognitive enhancement. ACS Chem Neurosci. 2019;10(3):1137-48. https:// doi.org/10.1021/acschemneuro.8b00571.

104. Gaber T. Assessment and management of post-COVID fatigue. Progress in Neurology and Psychiatry. 2021;25(1):36-9. https:// doi.org/10.1002/pnp.698.

105. Miners S, Kehoe PG, Love S. Cognitive impact of COVID-19: looking beyond the short term. Alzheimers Res Ther. 2020;12(1): 170. https://doi.org/10.1186/s13195-020-00744-w.

106. The Lancet N. Long COVID: understanding the neurological effects. The Lancet Neurology. 2021;20(4):247. https://doi.org/10. 1016/S1474-4422(21)00059-4.
107. Beghi E, Helbok R, Crean M, Chou SH, McNett M, Moro E, et al. The European Academy of Neurology COVID-19 registry (ENERGY): an international instrument for surveillance of neurological complications in patients with COVID-19. Eur J Neurol. 2020. https://doi.org/10.1111/ene.14652.

108. Helbok R, Chou SH, Beghi E, Mainali S, Frontera J, Robertson C, et al. NeuroCOVID: it's time to join forces globally. Lancet Neurol. 2020;19(10):805-6. https://doi.org/10.1016/S14744422(20)30322-7.

109. Roman GC, Spencer PS, Reis J, Buguet A, Faris MEA, Katrak SM, et al. The neurology of COVID-19 revisited: a proposal from the Environmental Neurology Specialty Group of the World Federation of Neurology to implement international neurological registries. J Neurol Sci. 2020;414:116884. https://doi.org/10. 1016/j.jns.2020.116884.

110. Datta SD, Talwar A, Lee JT. A proposed framework and timeline of the spectrum of disease due to SARS-CoV-2 infection: illness beyond acute infection and public health implications. JAMA. 2020;324(22): 2251-2. doi:https://doi.org/10.1001/jama.2020.22717.

111. van Kampen JJA, van de Vijver D, Fraaij PLA, Haagmans BL, Lamers MM, Okba N, et al. Duration and key determinants of infectious virus shedding in hospitalized patients with coronavirus disease-2019 (COVID-19). Nat Commun. 2021;12(1):267. https://doi.org/10.1038/s41467-020-20568-4.

112. Stormorken E, Jason LA, Kirkevold M. Factors impacting the illness trajectory of post-infectious fatigue syndrome: a qualitative study of adults' experiences. BMC Public Health. 2017;17(1):952. https://doi.org/10.1186/s12889-017-4968-2.

113. Townsend L, Dyer AH, Jones K, Dunne J, Mooney A, Gaffney F, et al. Persistent fatigue following SARS-CoV-2 infection is common and independent of severity of initial infection. PLoS One. 2020;15(11):e0240784. https://doi.org/10.1371/journal.pone. 0240784.

114. Komaroff AL, Bateman L. Will COVID-19 lead to myalgic encephalomyelitis/chronic fatigue syndrome? Front Med (Lausanne). 2020;7:606824. https://doi.org/10.3389/fmed.2020. 606824.

115. Moreh E, Jacobs JM, Stessman J. Fatigue, function, and mortality in older adults. J Gerontol A Biol Sci Med Sci. 2010;65(8):88795. https://doi.org/10.1093/gerona/glq064.

116. Franceschi C, Garagnani P, Parini P, Giuliani C, Santoro A. Inflammaging: a new immune-metabolic viewpoint for agerelated diseases. Nat Rev Endocrinol. 2018;14(10):576-90. https://doi.org/10.1038/s41574-018-0059-4.

117. Zhou F, Yu T, Du R, Fan G, Liu Y, Liu Z, et al. Clinical course and risk factors for mortality of adult inpatients with COVID-19 in Wuhan, China: a retrospective cohort study. Lancet. 2020;395(10229):1054-62. https://doi.org/10.1016/S01406736(20)30566-3.

118. Jordan RE, Adab P, Cheng KK. Covid-19: risk factors for severe disease and death. BMJ. 2020;368:m1198. https://doi.org/10. 1136/bmj.m1198.

119. Petrie JG, Cheng C, Malosh RE, VanWormer JJ, Flannery B, Zimmerman RK, et al. Illness severity and work productivity loss among working adults with medically attended acute respiratory illnesses: US influenza vaccine effectiveness network 2012-2013. Clin Infect Dis. 2016;62(4):448-55. https://doi.org/10.1093/cid/ civ952.

120. Perez M, Jaundoo R, Hilton K, Del Alamo A, Gemayel K, Klimas $\mathrm{NG}$, et al. Genetic predisposition for immune system, hormone, and metabolic dysfunction in myalgic encephalomyelitis/chronic fatigue syndrome: a pilot study. Front Pediatr. 2019;7:206. https:// doi.org/10.3389/fped.2019.00206.

121. Cope H, David A, Pelosi A, Mann A. Predictors of chronic "postviral" fatigue. Lancet. 1994;344(8926):864-8. https://doi. org/10.1016/s0140-6736(94)92833-9. 
122. Jason LA, Katz BZ, Shiraishi Y, Mears CJ, Im Y, Taylor R. Predictors of post-infectious chronic fatigue syndrome in adolescents. Health Psychol Behav Med. 2014;2(1):41-51. https://doi. org/10.1080/21642850.2013.869176.

123. Kokubun K, Nemoto K, Oka H, Fukuda H, Yamakawa Y, Watanabe Y. Association of fatigue and stress with gray matter volume. Front Behav Neurosci. 2018;12:154. https://doi.org/10. 3389/fnbeh.2018.00154

124. Klok FA, Boon G, Barco S, Endres M, Geelhoed JJM, Knauss S, et al. The post-COVID-19 Functional Status scale: a tool to measure functional status over time after COVID-19. Eur Respir J. 2020;56(1). https://doi.org/10.1183/13993003.01494-2020.

125. Kalin A, Javid B, Knight M, Inada-Kim M, Greenhalgh T. Direct and indirect evidence of efficacy and safety of rapid exercise tests for exertional desaturation in Covid-19: a rapid systematic review. Syst Rev. 2021;10(1):77. https://doi.org/10.1186/s13643-021-01620-w.

126. Mantha S, Tripuraneni SL, Roizen MF, Fleisher LA. Proposed modifications in the 6-Minute Walk Test for potential application in patients with mild COVID-19: a step to optimize triage guidelines. Anesth Analg. 2020;131(2):398-402. https://doi.org/10. 1213/ANE.0000000000004986.

127. Ortelli P, Ferrazzoli D, Sebastianelli L, Engl M, Romanello R, Nardone R, et al. Neuropsychological and neurophysiological correlates of fatigue in post-acute patients with neurological manifestations of COVID-19: Insights into a challenging symptom. J Neurol Sci. 2021;420:117271. https://doi.org/10.1016/j.jns.2020. 117271

128. Barker-Davies RM, O'Sullivan O, Senaratne KPP, Baker P, Cranley $\mathrm{M}$, Dharm-Datta S, et al. The Stanford Hall consensus statement for post-COVID-19 rehabilitation. Br J Sports Med. 2020;54(16):949 59. https://doi.org/10.1136/bjsports-2020-102596.

129. Friedman KJ, Murovska M, Pheby DFH, Zalewski P. Our Evolving Understanding of ME/CFS. Medicina (Kaunas). 2021;57(3). https://doi.org/10.3390/medicina57030200.

130. Lim EJ, Son CG. Review of case definitions for myalgic encephalomyelitis/chronic fatigue syndrome (ME/CFS). J Transl Med. 2020;18(1):289. https://doi.org/10.1186/s12967-020-02455-0.

131. Jason LA, Benton MC, Valentine L, Johnson A, Torres-Harding $\mathrm{S}$. The economic impact of ME/CFS: individual and societal costs. Dyn Med. 2008;7:6. https://doi.org/10.1186/1476-5918-7-6.

132. Toogood PL, Clauw DJ, Phadke S, Hoffman D. Myalgic encephalomyelitis/chronic fatigue syndrome (ME/CFS): where will the drugs come from? Pharmacol Res. 2021;165:105465. https://doi.org/10.1016/j.phrs.2021.105465.

133. Hickie IB, Wilson AJ, Wright JM, Bennett BK, Wakefield D, Lloyd AR. A randomized, double-blind placebo-controlled trial of moclobemide in patients with chronic fatigue syndrome. J Clin Psychiatry. 2000;61(9):643-8. https://doi.org/10.4088/jcp. v61n0909.

134. Blockmans D, Persoons P, Van Houdenhove B, Bobbaers H. Does methylphenidate reduce the symptoms of chronic fatigue syndrome? Am J Med. 2006;119(2):167 e23-30. https://doi.org/ 10.1016/j.amjmed.2005.07.047.

135. Kaiser JD. A prospective, proof-of-concept investigation of KPAX002 in chronic fatigue syndrome. Int J Clin Exp Med. 2015;8(7):11064-74.

136. Straus SE, Dale JK, Tobi M, Lawley T, Preble O, Blaese RM, et al. Acyclovir treatment of the chronic fatigue syndrome. Lack of efficacy in a placebo-controlled trial. N Engl J Med. 1988;319(26):1692-8. https://doi.org/10.1056/NEJM198812293192602.

137. Mitchell WM. Efficacy of rintatolimod in the treatment of chronic fatigue syndrome/myalgic encephalomyelitis (CFS/ME). Expert Rev Clin Pharmacol. 2016;9(6):755-70. https://doi.org/10.1586/ 17512433.2016 .1172960 .
138. Strayer DR, Carter WA, Stouch BC, Stevens SR, Bateman L, Cimoch PJ, et al. A double-blind, placebo-controlled, randomized, clinical trial of the TLR-3 agonist rintatolimod in severe cases of chronic fatigue syndrome. PLoS One. 2012;7(3):e31334. https:// doi.org/10.1371/journal.pone.0031334.

139. Roerink ME, Bredie SJH, Heijnen M, Dinarello CA, Knoop H, Van der Meer JWM. Cytokine inhibition in patients with chronic fatigue syndrome: a randomized trial. Ann Intern Med. 2017;166(8):557-64. https://doi.org/10.7326/m16-2391.

140. Fluge Ø, Risa K, Lunde S, Alme K, Rekeland IG, Sapkota D, et al. B-lymphocyte depletion in myalgic encephalopathy/chronic fatigue syndrome. An Open-Label Phase II Study with Rituximab Maintenance Treatment. PLoS One. 2015;10(7):e0129898. https://doi.org/10.1371/journal.pone.0129898.

141. Rekeland IG, Fossa A, Lande A, Ktoridou-Valen I, Sorland K, Holsen $\mathrm{M}$, et al. Intravenous cyclophosphamide in myalgic encephalomyelitis/chronic fatigue syndrome. An Open-Label Phase II Study. Front Med (Lausanne). 2020;7:162. https://doi. org/10.3389/fmed.2020.00162.

142. Cleare AJ, Heap E, Malhi GS, Wessely S, O'Keane V, Miell J. Low-dose hydrocortisone in chronic fatigue syndrome: a randomised crossover trial. Lancet. 1999;353(9151):455-8. https://doi.org/10.1016/S0140-6736(98)04074-4.

143. McKenzie R, O'Fallon A, Dale J, Demitrack M, Sharma G, Deloria M, et al. Low-dose hydrocortisone for treatment of chronic fatigue syndrome: a randomized controlled trial. JAMA. 1998;280(12):1061-6. https://doi.org/10.1001/jama.280.12.1061.

144. Hermans L, Nijs J, Calders P, De Clerck L, Moorkens G, Hans G, et al. Influence of morphine and naloxone on pain modulation in rheumatoid arthritis, chronic fatigue syndrome/fibromyalgia, and controls: a double-blind, randomized, placebo-controlled, crossover study. Pain Pract. 2018;18(4):418-30. https://doi.org/10. 1111/papr.12613.

145. Boomershine CS. Pregabalin for the management of fibromyalgia syndrome. J Pain Res. 2010;3:81-8. https://doi.org/10.2147/jpr. s7884.

146. Castro-Marrero J, Cordero MD, Segundo MJ, Saez-Francas N, Calvo N, Roman-Malo L, et al. Does oral coenzyme Q10 plus NADH supplementation improve fatigue and biochemical parameters in chronic fatigue syndrome? Antioxid Redox Signal. 2015;22(8):679-85. https://doi.org/10.1089/ars.2014.6181.

147. Tolle M, Freitag H, Antelmann M, Hartwig J, Schuchardt M, van der Giet M, et al. Myalgic encephalomyelitis/chronic fatigue syndrome: efficacy of repeat immunoadsorption. J Clin Med. 2020;9(8). https://doi.org/10.3390/jcm9082443.

148. Castro-Marrero J, Saez-Francas N, Santillo D, Alegre J. Treatment and management of chronic fatigue syndrome/myalgic encephalomyelitis: all roads lead to Rome. Br J Pharmacol. 2017;174(5): 345-69. https://doi.org/10.1111/bph.13702.

149. Torjesen I. NICE backtracks on graded exercise therapy and CBT in draft revision to CFS guidance. BMJ. 2020;371:m4356. https:// doi.org/10.1136/bmj.m4356.

150. Yong SJ. Long COVID or post-COVID-19 syndrome: putative pathophysiology, risk factors, and treatments. Infect Dis (Lond). 2021:1-18. https://doi.org/10.1080/23744235.2021.1924397.

151. Zhang K, Zhou X, Liu H, Hashimoto K. Treatment concerns for psychiatric symptoms in patients with COVID-19 with or without psychiatric disorders. Br J Psychiatry. 2020;217(1):351. https:// doi.org/10.1192/bjp.2020.84.

Publisher's Note Springer Nature remains neutral with regard to jurisdictional claims in published maps and institutional affiliations. 